\title{
Harm reduction in the context of psychoactive substances: nursing discourses in primary health care*
}

\author{
Redução de danos no contexto de substâncias psicoativas: \\ discursos da enfermagem da atenção primária à saúde \\ Reducción de daños en el contexto de las sustancias psicoactivas: \\ discursos de enfermería de la atención primaria de salud
}

How to cite this article:

Pereira SS, Nóbrega MPSS, Gonçalves AMS, Protti-Zanatta ST, Marcheti PM, Zerbetto SR. Harm reduction in the context of psychoactive substances: nursing discourses in primary health care. Rev Esc Enferm USP. 2021;55:e2020-0529. DOI: https://doi.org/10.1590/1980-220X-REEUSP-2020-0529

\section{Sarah Salvador Pereira ${ }^{1}$ \\ (D) Maria do Perpétuo Socorro de Sousa Nóbrega $^{2}$ \\ (iD) Angélica Martins de Souza Gonçalves ${ }^{1}$ \\ Simone Teresinha Protti-Zanatta ${ }^{1}$ \\ Priscila Maria Marcheti ${ }^{3}$ \\ Sonia Regina Zerbetto ${ }^{1}$}

* Extracted from the master thesis: "Os sentidos da redução de danos nos discursos de profissionais de enfermagem da atenção primária à saúde”,

Programa de Pós-Graduação em Enfermagem,

Universidade Federal de São Carlos, 2020.

${ }^{1}$ Universidade Federal de São Carlos,

Programa de Pós-graduação em

Enfermagem, São Carlos, SP, Brazil.

${ }^{2}$ Universidade de São Paulo, Programa de

Pós-graduação em Enfermagem, São Paulo,

SP, Brazil.

${ }^{3}$ Universidade Federal do Mato Grosso

do Sul, Programa de Pós-graduação em

Educação, Campo Grande, MS, Brazil.

\section{ABSTRACT}

Objective: To analyze the production of meanings on interventions considered as Harm Reduction in the discourses of nursing professionals working in Primary Health Care. Method: Qualitative study based on the theoretical-methodological framework of French Discourse Analysis. Semi-structured interviews were conducted with 14 nursing professionals working in Primary Health Care, from February to October 2019. Results: Most Harm Reduction practices performed by nursing professionals aim to minimize risks and physical damage. Harm Reduction actions that require welcoming, non-judgment and qualified listening were observed. Some nursing professionals perform Harm Reduction actions, but do not recognize them as such. Conclusion: The production of meanings in the discourses of nursing professionals presented evidence of biomedical and/or disease discursive formations, health prevention, interpersonal relationships and health promotion.

\section{DESCRIPTORS}

Address; Nursing; Harm Reduction; Primary Health Care; Substance-Related Disorders.
Corresponding author:

Sarah Salvador Pereira

Rua José Rodrigues da Silva, 224, Cruzeiro

37500-222 - Itajubá, MG, Brazil

sarahsalvadorpereira@gmail.com
Received: $11 / 30 / 2020$

Approved: 05/06/2021 


\section{INTRODUCTION}

The Harm Reduction (HR) strategy in the context of the use of psychoactive substances aims to minimize risks and damages, respecting the autonomy of the individual and considering the social, cultural and economic determinants involved in psychoactive substance use ${ }^{(1)}$. The most evident HR actions at the national level are syringe and sterilized material exchange programs; information and advice actions; distribution of kits; peer education and guidance provided in various health and social care services ${ }^{(2)}$. In the international scenario, the most reported actions are: substitution treatment for opioids with methadone and/or the buprenorphine/naloxone; needle/syringe distribution programs; supervised consumption rooms; overdose prevention; testing, vaccination and treatment of infectious diseases ${ }^{(2-4)}$.

HR in Primary Health Care (PHC) is established as a strategy built in cooperation with the user and with no repressive approaches that only require complete abstinence. Therefore, it promotes new possibilities of life and treatment and reduces prejudices related to people who use psychoactive substances ${ }^{(4)}$. This way, nursing professionals who work on $\mathrm{PHC}$ centers have an essential role in population health care and are able to identify community contexts that affect the health process and develop strategies for health prevention, protection and promotion ${ }^{(5)}$. These professionals have the skills to recognize the needs arising from psychoactive substance use and to promote favorable moments, both individually and collectively, to provide guidance and develop HR strategies ${ }^{(6)}$.

However, the lack of a training focused on the approach to the user, both in universities and at work, represents an obstacle to the reception and qualified assistance of this population and generates misinformation and resistance regarding the HR guidelines ${ }^{(7)}$. In the national context, only few original studies investigate $\mathrm{HR}$ actions within the scope of PHC, and they are not focused on the nursing team, but on street office teams or community health workers ${ }^{(8-9)}$. Therefore, there is a gap in the scientific knowledge on HR interventions performed by $\mathrm{PHC}$ nursing professionals and specially in the study of these actions through discourse analysis.

The daily work in nursing involves dialogue between professionals and users and, consequently, discourse, in which speeches and words produce effects of meaning, which are products of the enunciations in their speeches, according to their concepts ${ }^{(10)}$. Understanding the discourse of nursing professionals can support the improvement of harm reduction practices and health care for users of primary services. Therefore, the objective of this study is to analyze the production of meanings about interventions considered as HR in the discourses of nursing professionals working in PHC.

\section{METHOD}

\section{Theoretical-Methodological Framework}

This study based on the theoretical-methodological framework of French DA, which understands that the discourse involves effects of meanings produced between subjects in their social places, determined by the social structure $^{(10)}$. One of the theoretical pillars of DA is Ideology (Althusser's conception), which is a mechanism that is part of the subjects, interpellates them, and is materialized in language ${ }^{(11)}$. Thus, ideological materiality is apprehended in the linguistic materiality ${ }^{(12)}$ in Discursive Formations, which consist of groups of speeches structured with regularities, historically determined in the scope of language and assembled in themes and ideological positions that appear in the speech of the subject of the discourse ${ }^{(11)}$. The ideology interpellates the subject and triggers the ideological subjection, in which the individual, through his speech, identifies with social class ideology (dominant class or not) without being aware of it and being able to transition from one social position to another ${ }^{(12)}$. Thus, in DA, Ideology is not a worldview or concealment of reality, but a structuring mechanism of the meaning ${ }^{(11: 96)}$ in the speech, which produces a naturalization of the meanings ${ }^{(12)}$.

DA seeks to capture the meanings under the surface of discourse, going beyond what is said or not said. Thus, it allows interpreting the discourse by identifying the traces and marks of the ideological, historical and social context, which are not organized by the enunciators themselves, but revealed in the linguistic materiality ${ }^{(11)}$. Therefore, DA seeks to understand and interpret how a symbolic object (statement, text, music, painting, among others) produces meanings and explains meanings for and by the subject of the discourse ${ }^{(11)}$. DA involves discursive memories, which are the semantic basis of a discourse, as they are linguistic marks of subjects and discourses pre-constructed collectively and externally ${ }^{(11)}$. Discourses are interpellated by ideological formations, representations that are not individual or universal, but reveal themselves in social class and in ideological/political relations of conflict, alliance or domination ${ }^{(10)}$.

\section{Type OF Study}

Qualitative, exploratory study guided by the Consolidated Criteria for Reporting Qualitative Research (COREQ).

\section{SCENARIO}

Two Primary Health Centers (PHC) and eight Family Health Centers (FHC) agreed to participate in this study, with at least one health center in each administrative region of a city in the state of São Paulo (in a total of five regions). This fact is justified by the intention of capturing the perception of nursing professionals in these different territories and types of health centers. 


\section{Population}

Fifteen nursing professionals representing the health centers of their respective administrative regions were contacted. One of them refused to participate in the research, without justification. Recruitment was done by telephone, with intentional sampling, considering the nursing teams of the health centers, and was closed by convenience ${ }^{(13)}$ with 14 professionals (nine nurses, four nursing assistants and one nursing technician). Inclusion criteria were: being at least 18 years old, working in the service for at least 1 year (bond with the population, knowledge of local characteristics, effective and/or temporary employment bond). Professionals on vacation, sick leave or paternity/maternity leave were excluded.

\section{Data Collection}

Semi-structured interviews were conducted from February to October 2019 in the nursing offices/procedural rooms of the health centers by the first author of this study and master's student, with the guiding question: What actions have been implemented for users and their families in this center that you consider to be HR? According to the responses of the participants, other questions were asked to deepen the knowledge on the strategies used. Interviews had an average duration of 24 minutes and were audio-recorded and fully transcribed. The interview script was improved after two pilot interviews. Participants were identified as Discursive Subjects (DS) and a number representing the order of the interview. The discursive sequences were represented by the acronym "ds", followed by a number, and texts with linguistic traces and marks were underlined.

\section{Data Analysis}

The analysis was done simultaneously by two researchers, according to the analytical devices of the DA methodological framework. In the 1st stage, the researchers listened to the material and transcribed the interviews for the constitution of the corpus of analysis. This stage is the transition from the linguistic surface to the discursive object, and the traces, marks and signs were marked for the understanding of the discourse on HR actions. The 2nd stage was the transition from the object to the discursive process and it sought to interpret the historicity of the text (the event of the text as discourse and its meanings) materialized in the discourse and how ideology is inscribed in this discourse, that is, the position taken by the subject when joining a discourse. The "contents" of the history are not captured directly in the texts, but apprehended in their discursive materiality that is related to exteriority. The first cutouts of the corpus of analysis were made after selecting the relevant and regular discursive segments outlining the discursive formations ${ }^{(11)}$.

In the 3rd stage, the transformation of the discursive process into ideological formation, the discursive segments were grouped into discursive blocks, according to similar ideological formations ${ }^{(11)}$. The analysis highlighted the discursive block: the effects of meaning involved in the practice of professionals. Two nurse researchers, one specialized in
HR and the other in DA, evaluated the discursive sequences, the excerpts and the final discursive blocks to ensure the validity and reliability of the results as recommended in the literature ${ }^{(14)}$.

\section{Ethical Aspects}

This study was approved by the Ethics Committee for Research with Human Beings of a Federal University in 2018 protocol \#3,077,819. The study complies with Resolution 466/12 and 510/16. The participants signed the Informed Consent Term.

\section{RESULTS}

All participants are female, with a median age of 41 years old and a mean time of 17 years of professional practice. Eight of these professionals participated in some training in Mental Health or alcohol and other drugs. Most participants self-identified as white, married and Catholic.

The discursive block addressed the production of effects of meaning that evidenced discursive formations in HR from a biomedical and/or disease-associated perspective, health prevention interventions, interpersonal relationships and health promotion. Excerpts 1 and 2 indicated nursing actions anchored in biomedical and technical discursive formations.

Excerpt 1: The doctor provides a lot of treatment here for those who want to quit using, he gives medication, we schedule it every week, they come one week to talk to him, and another week to talk to me. So, we try (ds8) (...) I brought him here, to the center, I scheduled a consultation with a doctor and then he agreed to do the treatment. The doctor started the medication and... and then he came every week at the beginning (ds9). (DS10).

Excerpt 2: So, we only do the medication part, we check blood pressure (...) we do it, but we don't comment (ds8). (DS12).

In excerpts 3 to 6 , the DS described HR actions developed for health prevention, focused on reducing risks and physical damage in the context of Sexually Transmitted Infections (STIs) and gynecological diseases, considering the vulnerability of this population.

Excerpt 3: I was going to offer a quick test, which is what we have here, right? Because they are very vulnerable... for girls (...) then if it were a girl, I was going to try, I don't know, to take a Pap smear and give her guidance on nutrition (ds9). (DS9).

Excerpt 4 showed signs of care for the adolescent user, which was not limited to the psychoactive substance itself, but included the prevention of unwanted pregnancies.

Excerpt 4: They [CAPS AD teams [Alcohol and Drugs Psychosocial Care Center] and CAPSi [Child Psychosocial Care Center]] gave psychological support to the girl [user], but they say: (I think they are right) "Keep using marijuana..." (laughs) "But take this contraceptive..." (ds9). (DS5). 
Excerpts 5 and 6 of the DSs listed guidelines on the risk of STIs, reinforcing the perception of a very vulnerable population.

Excerpt 5: what they [psychoactive substance users] have more contact with are sexually transmitted infections. Even because they share a lot, right? (sd22). Then I would... try to explain this issue to them and reduce the damage. They caught a disease that... for them it can... more than they already have... it could be a disease, a chronic disease... HIV, syphilis, right? (ds23). (DS9).

Excerpt 6: So now that he's got the courage [to be admitted to the Therapeutic Community] to do it, now he has another problem, which is HIV, but he knows he was at risk, right, he was already on the street, and had a behavior (...) a suspicious behavior of sexual exposure (sd18) (...) So, my role is to really talk about the consequences, right, and tell him that he will be exposed to other, to other diseases, right (ds19). (DS11).

In excerpts 7 to 9, DSs performed HR actions involving interpersonal relationships, even though they did not recognize them, such as welcoming and qualified listening, as well as guidelines for drug replacement treatment.

Excerpt 7: So, I even gave him guidance, I said: "[DS1's relative name], yeah... leave the cocaine and use marijuana instead of cocaine, I even guided him, (...) and I know that it is not correct right? All of them are drugs, cocaine and marijuana (ds6). (DS1).

Excerpt 8: I think we have to hear the patients and let them express their wishes (ds19) I don't know if there's another way, but for me it's listening, making them comfortable, giving them the freedom of choice, because we can't change a person's life if they don't allow it, right? (ds20). (DS8).

Excerpt 9: It would be basically giving them guidance, right, helping, (...) they need a more humane care, more than simply going to the doctor, taking medication and leaving (ds7). (DS13).

The HR actions mentioned in excerpts 10 to 12 by DS who had knowledge about this strategy prioritized dialogue, pacts with the user. and their freedom of choice.

Excerpt 10: So if they [psychoactive substance user] cannot do it, I'm not going to tell them: "you can never use marijuana again". "Use less, use it at this time...". I can make some suggestions for them, to reduce the risk (...) (ds1). In practice, it is guidance. We use resources like computers, media, these things, but it is guidance. Conversation, dialogue, bonding, providing a little more security for the patient, showing support (ds4). (DS5).

Excerpt 11: We talk, we talk about... how they could improve. We sometimes create... establish times for them, right? What they could improve in their life with that time... If they want it for their lives... What is the future they see for themselves, or for their children, or their family, if they ever stopped, right? What is the time of day they want it the most? So, we do it as if it were individual guidance, you know?" (ds11). (DS6).

Excerpt 12: If we judge, (...), we already have a broken bond, which will probably be very difficult to rebuild (ds8). (DS7).
Excerpt 13 demonstrated collective health promotion actions, which involve integrative and complementary practices (ICPs).

Excerpt 13: We still don't have a group in this area of mental health... but we also have a physical therapist and a dentist who work with acupuncture and auriculotherapy, so there is also this support... (ds13). (...) we are making a garden group, we have a community garden, and we were making some groups at the school... and we... as we work together with the community center, we also have a physical activity and a cooking group (...) there is a partnership. So, now we have here... we have stretching class, handicrafts class (ds14). (DS10).

\section{DISCUSSION}

The effects of meaning related to the practice of $\mathrm{PHC}$ nursing professionals encompass different knowledge and practices affected by discursive memories and ideological positions of HR discourses in biomedical and/or disease perspectives, health prevention, interpersonal relations and health promotion.

The Excerpts 1 and 2 present discursive memories of the biomedical health paradigm and textual evidence of the power relations on medical knowledge. The biomedical model values the sharing of tasks and medical knowledge emphasizes diseases, drug treatment and hospitalization ${ }^{(15)}$. The subject-position of the professional reveals a dominant ideological formation historically determined by the social and technical division of work ${ }^{(16)}$. The historical production conditions ${ }^{(11)}$ allow observing effects of meanings that derive from the capitalist mode of production, which reinforces the technical division of health work between nursing and medicine. This is present in the organization and production of care provided to users ${ }^{(15)}$, which reproduces the pathologizing discourses of hierarchical work centered on medical knowledge. On the other hand, HR aims to take care of this user in an interdisciplinary perspective and in a network of care, with the support of the other professionals and health devices in the territory, which constitute the health and psychosocial care network.

In Excerpt 2, the technical assistance discourse mentions only technical nursing care actions performed to the user, such as monitoring medications and measuring vital signs. In the HR strategy, it is also relevant to establish intersubjective interactions (between subjects), which involve therapeutic listening, welcoming, sharing of needs, responsibilities, and respect for the care that will be decided together. These behaviors focus on the subject's singularity and subjectivity and their living and dynamic territory ${ }^{(17)}$.

Other HR actions that came up in this study involve health education, prevention of physical and biological risk, such as rapid testing for STIs, guidance on risks and prevention of gynecological diseases and unwanted pregnancy. The guidelines of health policies on alcohol and other drugs in Brazil and in the world are based on the paradigms of war on drugs and HR. The first is based on ideas of social intolerance, prohibitionism, and criminalization of the circulation and use of psychoactive substances ${ }^{(18)}$, which can 
give rise to a clandestine market, while the second involves health actions aimed at reducing the risks and damage caused by the use of these substances. It is understood that the use of these substances is a personal choice related to multiple factors, such as psychological constitution, family functioning, and adverse situations experienced by the subjects ${ }^{(18)}$.

Excerpt 5 mentions HR guidelines for the prevention of STIs such as HIV and Syphilis, considered as a high risk related to the consumption of psychoactive substances. The ds 23 reveals evidence that psychoactive substance use use/abuse/dependence is already considered a disease and, therefore, it is necessary to prevent the emergence of other diseases (AIDS, syphilis).

Excerpt 6 also mentions STI prevention and associates psychoactive substance use with high risk behaviors for STIs. A metaphorical transfer of meaning is perceived in the association between the significant "risk behavior" and "suspicious" and the generalization that every person who uses psychoactive substances and/or is homeless has a behavior considered suspicious and risky and is more susceptible to STIs. The effects of meaning are constructed through generalization, blaming, stigmatization, and moral judgment, which hinder the access of users to health services and treatment, as well as their engagement and adherence to therapy ${ }^{(19)}$.

It is important that nursing professionals listen to the life experiences of this specific population and establish a therapeutic alliance to plan care together with the user. It is necessary that nursing professionals confront false beliefs that every homeless person is a psychoactive substance user and is exposed to STIs. This attitude promotes conditions so that pre-exposure and post-exposure HIV prophylaxis can be performed if necessary and/or accepted by the user. The discursive sequences also evidence ideological conceptions of the "risk behavior" concept, arising from discursive memories of the 1980s and 1990s in Brazil. In those years, with the increase in HIV infections, certain segments of the population were classified as "risk groups" (homosexual men, homeless people, and psychoactive substance users). It was also during this period that the first HR initiatives emerged, with the distribution of sterile material to avoid the incidence of STIs ${ }^{(20)}$. The concept of "risk behavior" was fundamental to traditional epidemiology; however, it is believed that the use of psychoactive substances involves factors that go beyond this perspective, as it is a complex, broad and socially determined phenomenon. Later on, the concept of situation of vulnerability allowed understanding that the "problem" of psychoactive substance use is not limited to the individual dimension or "risk behavior", but it is related to situations of economic, social and political vulnerability, which cannot be disregarded in the planning of HR actions ${ }^{(21)}$.

Studies ${ }^{(18,22)}$ sought to problematize the phenomenon of psychoactive substance use from the perspective of collective health, in which such problem is socially determined and, therefore, is a reflection of the complex network of production, circulation and use of psychoactive substances that is correlated to the capitalist mode of production. In this perspective, the so-called emancipatory HR is based on a critical analysis of the situation of vulnerability and marginalization of these social groups, understanding it as social inequality. Thus, the HR trend in the liberal approach ${ }^{(18)}$ values the users' freedom of choice to use psychoactive substances and their human rights and uses, in the context of mental health, pragmatic HR strategies that guarantee citizenship and humane health care, as well as actions that mitigate the social needs and vulnerabilities of these groups. However, these actions do not address the origin of the problem and neither mobilize and equip vulnerable and marginalized social groups to demand solutions to their health needs ${ }^{(18)}$, impairing the path towards broad transformations in society and in the "problem" of psychoactive substances.

Two nursing professionals (DS5 and DS1), ideologically subjected, materialize in their speeches a liberal and conservative HR trend in relation to the topic of psychoactive substances, moving between the subject positions, that is, sometimes as health professionals, sometimes as women and sometimes as religious people. One of them (DS5), when laughing, expressing a non-verbal language, reveals evidence of uneasiness in her position-subject of a FHU nurse, expressing effects of meaning of denial of her own speech, manifested in the contradiction and uneasiness of her attitude as a professional nurse in a territory of high social vulnerability. However, her recommendation is in line with the HR principles ${ }^{(2)}$, as not censoring the use of psychoactive substances is a form of approximation between professional and user, allowing the user to keep receiving care, regardless of their use of psychoactive substances, and avoiding the distance between the user, the center and the health professional.

Another professional (DS1), in her position-subject of a relative of someone who used psychoactive substances, gives her family member the advice to replace a psychoactive substance considered more harmful for a less harmful one, which is one of the guidance strategies for HR. Substitution therapy is a strategy that has been disseminated for a long time and extended to other countries and contexts of use, but was initially aimed at people with opioid dependence who were prescribed substitute drugs, mainly in Europe. It has the objective of preventing damage from withdrawal and abstinence and preventing the risk of overdose ${ }^{(2)}$. This is a useful strategy that provides opportunities to facilitate health guidelines.

The conflict of DS1, in Excerpt 7, ds16, occurs because she believes that the guidance given is not correct, considering that all psychoactive substances are drugs. The ambivalent effects of meanings in the professional's discourse affect the guidance given to the family member. Given the condition of production of the materiality of the discourse of this professional (in the health center) and her subject-positions as a religious woman, a health professional and a relative of a psychoactive substance user, it is possible to notice an alternation of the positions-subjects assumed by the professional. It is assumed that as a health professional and as a religious woman, she believes that this advice 
is not correct. However, for her family member, she provides HR guidelines (despite her ignorance of this conscious knowledge), which denotes a materialized heterogeneous discourse with different subjects and knowledge ${ }^{(11)}$. In the DA perspective, the individual is a subject with an ideological functioning. Therefore, their place in society influences what they enunciate ${ }^{(23)}$. The DS enunciates something that has already been said about HR elsewhere, representing a discursive memory. According to the subject-position, the participants assume ideological formations of discourses with a conservative or liberal trend. A study points out that the conservative trend is based on moral and religious arguments, which increases guilt, places the responsibility of consumption and abstinence on the user, and advocates religious practices of salvation ${ }^{(18)}$.

Excerpts 8 and 9 also prioritize HR principles in care, as they emphasize qualified listening and value the subject's wishes $^{(24)}$ and the humanization of care ${ }^{(25)}$. The verbal signifiers "hear" and "listen", as well as the fragments "express wishes", "make comfortable" and "freedom of choice" are traces that reinforce the effects of a sense of attention, respect, freedom and humane care, which are in the liberal trend of the HR strategy. The term humanization derives from a sense of recovering the human essence, rescuing what is lost from human nature. The polysemy and breadth of the term "humanization" allows for countless interpretations, such as human-centered care or attitudes of empathy and support towards the other as the basis of the professional-user relationship ${ }^{(25)}$. A space that welcomes the demands and expectations of another human being is where HR is inserted, as a strategy that is consolidated in the relationship with the other, without judgments, but with exchanges and understanding.

In Excerpts 10 to 12, professionals who reported having prior knowledge about $\mathrm{HR}$, produced care actions based on HR assumptions, with unique and contextualized guidelines that did not impose or condemn, and did not immediately indicate abrupt abstinence. In excerpt $10, \mathrm{DS}$ alludes to the importance of qualified listening and bonding, corroborating a study ${ }^{(26)}$ that highlights dialogue as a way of valuing self-esteem, self-care, life project and exchange of experiences.

In Excerpt 11, the individualized guidelines are based on the subject's life context and history of use, and stipulate goals. In a metaphorical effect, the signifiers "times" and "future" represent "goals", "deadlines", in a pact with the subject which admits that changes occur over "time", that is, it is a process that is built in the long term, in a temporal perspective, in the future, without immediatist measures. A study with harm reduction professionals from the state of Rio Grande do Sul pointed out that, when performing their work, these professionals aim to help users in the future transformation of their lives, in the family, work and therapeutic aspects, among others ${ }^{(27)}$. Excerpt 12 presents the signifiers "break" and "rebuild" which are traces of metaphorical effects of rupture and (re)construction of bonds between nursing professionals and psychoactive substance users. It is important to avoid judging the user for their consumption, as this attitude allows an approximation between user and professional and enhances the participation of the subject in their treatment.

Other actions mentioned in Excerpt 13 were health promotion actions extended to the community, such as Integrative and Complementary Practices (acupuncture and auriculotherapy), groups/workshops of physical, manual and artistic activities, which were not mentioned by the interviewees as specific for psychoactive substance users but promote health, well-being, interaction and social eintegration. The Integrative and Complementary Practices activities can reduce anxiety, improve mood and the ability to deal with emotions, and improve the relationship between the professional and the user ${ }^{(28)}$. Other practices could integrate the set of practices in HR, such as group activities, community therapy, educational groups, interdisciplinary consultations, promotion of spaces for exchanges between users and professionals, and intersectoral activities that promote integration of users into the community ${ }^{(29)}$. A study points to the need to overcome the pragmatic strategies commonly implemented, which do not always meet the particularities of each subject/population, and to carry out emancipatory HR practices that promote, among health professionals and users, reflections on the origin of health problems, giving them the means to demand decisive actions regarding their health needs and analyze the problems involved in the production, circulation and use of psychoactive substances ${ }^{(22)}$.

Knowing the HR actions performed by the PHC nursing professionals and the effects of meaning in their professional practices allows the identification of gaps in training that reflect on health practice. It is possible to question to what extent did these professionals receive theoretical and practical support in undergraduate and/or technical nursing education on the concepts and scope of HR interventions, which are not limited only to the liberal trend of HR, but include an emancipatory HR. A study ${ }^{(29)}$ indicates that mental health studies in the training of the nursing professional meet the current social demands and the reality experienced, but must also be coordinated with the theoretical and political trends in the area of mental health and with the collective health needs in the current context. The current Curriculum Guidelines for Nursing Courses aim to promote humane, critical and reflective training, and need to be aligned with the precepts of the Psychiatric Reform ${ }^{(29)}$.

Nevertheless, the adoption a broadened and psychosocial perspective to the detriment of the sole study of psychopathologies and symptoms generates challenges and resistance among educators and students who must operate in a new model ${ }^{(29)}$. The lack of coordination between collective health and mental health disciplines is an obstacle to the training nursing professionals ${ }^{(30)}$. A study ${ }^{(30)}$ reported some barriers in health institutions (university and health services) that can hinder the teaching of mental health applied to the context of PHC, such as: limited workload, lack of teachers to conduct the practice in PHC scenarios, and resistance of health teams/center managers. These difficulties can 
directly reflect on the actions and speeches of students, future professionals.

The nursing professionals in this study perform several HR interventions in PHC, supported by different discursive memories and ideological positions. The findings point to the importance of discussing the content of HR in the context of technical and higher education training, as well as in the context of professional qualification through continuing education. Literature ${ }^{(8,22)}$ indicates educational approaches based on scientific evidence that promote critical awareness, aiming to problematize and transform the context of reality. In additions, it points to the importance of identifying and reflecting on the local social needs of the population assigned to the health service, especially on the consumption of psychoactive substances, associated with the process of social reproduction in matters of physical structure, work and leisure possible in the communities ${ }^{(18)}$.

The limitation of this study is related to the lack of validation of the results with the study participants. Nevertheless, the study gave a voice to the different professional categories of nursing in different PHC territories in the studied city, which care for psychoactive substance users in different contexts of social vulnerability and develop health practices historically influenced by the social and technical division of work.

\section{CONCLUSION}

The effects of meaning on HR interventions present in the discourses of nursing professionals in this study included evidence of discursive formations in the biomedical and disease perspective, health prevention, interpersonal relationships, and health promotion. The study can support educational proposals on HR interventions in the training and qualification of nursing professionals, and it demonstrates the relevance of maintaining this strategy as a health policy. It is believed that this study can inspire discussions about the fundamental role of the nurse in the dissemination of HR, especially in PHC, and the construction of public policies. Finally, it is important to consider HR as more than a scope of technical procedures, but as an ethical and political posture allied to the precepts of the Psychiatric Reform and based on evidence.

\section{RESUMO}

Objetivo: Analisar a produção de sentidos sobre intervenções consideradas de Redução de Danos nos discursos dos profissionais de enfermagem que atuam na Atenção Primária à Saúde. Método: Estudo qualitativo embasado no referencial teórico-metodológico da Análise de Discurso de matriz francesa. Foram conduzidas entrevistas semiestruturadas com 14 profissionais de enfermagem atuantes na Atenção Primária à Saúde, no período de fevereiro a outubro de 2019. Resultados: A maioria das práticas de Redução de Danos, executadas pelos profissionais de enfermagem, está direcionada para minimizar riscos e danos físicos. Observaram-se ações de Redução de Danos que pressupõem o acolhimento, o não julgamento e a escuta qualificada do usuário. Alguns profissionais de enfermagem executam ações de Redução de Danos, mesmo não as reconhecendo como tais. Conclusão: A produção de sentidos nos discursos dos profissionais de enfermagem abarcou indícios de formações discursivas biomédica e/ou de doença, de prevenção à saúde, de relações interpessoais e de promoção à saúde.

\section{DESCRITORES}

Discurso; Enfermagem; Redução do Dano; Atenção Primária à Saúde; Transtornos Relacionados ao Uso de Substâncias.

\section{RESUMEN}

Objetivo: Analizar la producción de sentidos sobre intervenciones consideradas de Reducción de Daños en los discursos de los profesionales de enfermería que actúan en la Atención Primaria de Salud. Método: Se trata de un estudio cualitativo basado en el referencial teórico-metodológico del Análisis del Discurso de matriz francesa. Se condujeron entrevistas semiestructuradas con 14 profesionales de enfermería actuantes en la Atención Primaria de Salud, en el periodo comprendido entre febrero y octubre de 2019. Resultados: La mayoría de las prácticas de Reducción de Daños, realizadas por los profesionales de enfermería, están dirigidas a minimizar los riesgos y el daño físico. Se observaron acciones de Reducción de Daños que presuponen el acogimiento, el no juzgar y la escucha cualificada del usuario. Algunos profesionales de enfermería llevan a cabo acciones de Reducción de Daños, incluso sin reconocerlas como tales. Conclusión: La producción de sentidos en los discursos de los profesionales de enfermería mostró indicios de formaciones discursivas biomédicas y/o de enfermedades, de prevención de la salud, de relaciones interpersonales y de promoción de la salud.

\section{DESCRIPTORES}

Discurso; Enfermería; Reducción del Daño; Atención Primaria de Salud; Trastornos Relacionados con Sustancias.

\section{REFERENCES}

1. Teixeira MB, Ramôa ML, Engstrom E, Ribeiro JM. Tensions between approach paradigms in public policies on drugs: an analysis of Brazilian legislation in 2000-2016. Ciênc Saúde Colet. 2017;22:1455-66. DOI: http://dx.doi.org/10.1590/1413-81232017225.32772016.

2. Gomes TB, Vecchia MB. Harm reduction strategies regarding the misuse of alcohol and other drugs: a review of the literature. Ciênc Saúde Colet. 2018;23:2327-38. DOI: http://dx.doi.org/10.1590/1413-81232018237.21152016.

3. Bosque-Prous M, Brugal MT. Harm reduction interventions in drug users: current situation and recommendations. Gac Sanit. 2016;30: 99-105. DOI: https://doi.org/10.1016/j.gaceta.2016.04.020.

4. Soares NSA, Fernandes MA, Ribeiro HKP, Rocha DM, Ribeiro Ítalo AP. Harm reduction in primary healthcare: na integrative review of care strategies. Rev Esc Enferm USP. 2020;54:e03591. DOI: http://dx.doi.org/10.1590/s1980-220x2018051803591.

5. Fortuna CM, Matumoto S, Mishima SM, Rodríguez AMMM. Collective health nursing: desires and practices. Rev Bras Enferm. 2019;72: 336-40. DOI: http://dx.doi.org/10.1590/0034-7167-2017-0632. 
6. Farias LMS, Azevedo AK, Silva NMN, Lima JM. O enfermeiro e a assistência a usuários de drogas em serviços de atenção básica. Rev enferm UFPE on line. 2017;11:2871-80. DOI: https://doi.org/10.5205/reuol.11007-98133-3-SM.1107sup201708.

7. Lopes HP, Gonçalves AM. A política nacional de redução de danos: do paradigma da abstinência às ações de liberdade. Pesqu Prát Psicossoc [Internet]. 2018 [cited 2019 Jan 15];13(1):e1355. Available from: www.seer.ufsj.edu.br/index.php/revista_ppp/article/ view/2858/1886.

8. Engstrom EM, Teixeira MB. Manguinhos, Rio de Janeiro, Brazil, "Street Clinic" team: care and health promotion practice in a vulnerable territory. Ciênc Saúde Colet. 2016;2:1839-48. DOI: https://doi.org/10.1590/1413-81232015216.0782016.

9. Souza FÉ, Ronzani TM. Challenges to harm reduction practices in primary health care. Psicol Estud, Maringá. 2018;23:e2306. DOI: https:// doi.org/10.4025/psicolestud.v23.e37383.

10. Pêcheux M, Fuchs C. A propósito da análise automática do discurso: atualização e perspectivas (1975). In: Gadet F, Hak T, editors. Por uma análise automática do discurso. Uma introdução à obra de Michel Pêcheux. Campinas: Editora Unicamp; 2001. p. 163-252.

11. Orlandi EP. Análise de discurso: princípio e procedimentos. 12th ed. Campinas: Pontes Editores; 2015.

12. Pêcheux M. Semântica e discurso: uma crítica à afirmação do óbvio. 5th ed. Campinas: Editora Unicamp; 2014.

13. Etikan I, Musa SA, Alkassim RS. Comparison of convenience sampling and purposive sampling. American Journal of Theoretical and Applied Statistics. 2016;5:1-4. DOI: https://doi.org/10.11648/j.ajtas.20160501.11.

14. Noble H, Smith J. Issues of validity and reliability in qualitative research. Evid Based Nurs [Internet]. 2015 [cited 2019 Dec 19];18(2): 34-5. Available from: http://ebn.bmj.com/content/18/2/34.full.

15. Sousa PF, Maciel SC, Medeiros KT. Psychosocial X biomedical paradigm: where is the social representation anchored in psychic suffering? Trends Psychol. 2018;26:883-95. DOI: https://doi.org/10.9788/tp2018.2-13pt.

16. Leal JAL, Melo CMM. The nurses' work process in different countries: an integrative review. Rev Bras Enferm. 2018;71:413-23. DOI: https://doi.org/10.1590/0034-7167-2016-0468.

17. Silva AB, Olschowsky A, Wetzel C, Silva TJ, Rozado-Pedron A, Machado-Pavani F. The territorialities of care: interdisciplinary reflections on the use of drugs and sociocultural care. Rev Min Enferm. 2018;22:e-1150. DOI: http://www.dx.doi.org/10.5935/1415-2762.20180081.

18. Moreira CR, Soares CB, Campos CMS, Laranjo THM. Harm reduction: trends being disputed in health policies. Rev Bras Enferm. 2019;72:312-20. DOI: http://dx.doi.org/10.1590/0034-7167-2017-0671.

19. Degenhardt L, Wolfe D, Hall W, Hickman M, Chang J, Bruneau J, et al. Strategies to reduce drug-related harm: responding to the evidence base. Lancet. 2019;394:1490-3. DOI: https://doi.org/10.1016/S0140-6736(19)32232-9.

20. Santos VB, Miranda M. Projetos/Programas de redução de danos no Brasil: uma revisão de literatura. Rev Psic Diversidade e Saúde. 2016;5;106-18. DOI: http://dx.doi.org/10.17267/2317-3394rpds.v5i1.841.

21. Machado LV, Boarini ML. Políticas sobre drogas no Brasil: a estratégia de redução de danos. Psicol ciênc prof [Internet]. 2013 [cited 2017 Aug 15];33(3):580-95. Available from: http://www.scielo.br/scielo.php?pid=S141498932013000300006\&script=sci_abstract\&tlng=es.

22. Oliveira LC, Soares CB, Campos CMS, Cordeiro L. Emancipatory drug practices: building projects with Primary Healthcare workers. Rev Esc Enferm USP. 2019;53:e03528. DOI: http://dx.doi.org/10.1590/s1980-220x2018027803528.

23. Courtine JJ. Definição de orientações teóricas e construção de procedimentos em Análise do Discurso. Policromias [Internet]. 2016 [cited 2020 Mar 30];1(1):14-35. Available from: https://revistas.ufrj.br/index.php/policromias/article/view/4090.

24. Knaak S, Christie R, Mercer S, Stuart H. Harm reduction, stigma and the problem of low compassion satisfaction:tension on the front-lines of Canada's opioid crisis. J Mental Health Addic Nurs. 2019;3:8-21. DOI: https://doi.org/10.22374/jmhan.v3i1.37.

25. Sanches RCN, Gerhardt PC, Rêgo AS, Carreira L, Puplim JSL, Radovanovic CAT. Perceptions of health professionals about humanization in intensive care unit adult. Esc Anna Nery. 2016;20:48-54. DOI: https://doi.org/10.5935/1414-8145.20160007.

26. Lira LCS, Silva PMC, Clementino FS, Barbosa KKS. Entre políticas e práticas: atividades terapêuticas baseadas na redução de danos. Rev enferm UFPE on line. 2018;12:1206-15. DOI: https://doi.org/10.5205/1981-8963-v12i5a231307p1206-1215-2018.

27. Tisott ZL, Terra MG, Hildebrandt LM, Soccol KLS, Souto VT. Motives behind the work of harm reducers with drug users: a phenomenological study. Rev Gaúch Enferm. 2019;40:e20180062. DOI: https://doi.org/10.1590/1983-1447.2019.20180062.

28. Souza LP, Teixeira FL, Diniz AP, Souza AG, Delgado LHV, Vaz AM, et al. Práticas Integrativas e Complementares no cuidado à saúde mental e aos usuários de drogas. Id on Line Rev Mult Psic. 2017;11:177-98. DOI: https://doi.org/10.14295/idonline.v11i38.775.

29. Olmos CEF, Rodrigues J, Lino MM, Lino MM, Fernandes JD, Lazzari DD. Psychiatric nursing and mental health teaching in relation to Brazilian curriculum. Rev Bras Enferm. 2020;73:e20180200. DOI: http://dx.doi.org/10.1590/0034-7167-2018-0200.

30. Nóbrega MPSS, Venzel CMM, Sales ES, Próspero AC. Mental health nursing education in brazil: perspectives for primary health care. Texto Contexto Enferm. 2020;29:e20180441. DOI: http://dx.doi.org/10.1590/1980-265x-tce-2018-0441. 